\title{
The limited adoption of European-style military forces by eighteenth century rulers in India
}

\author{
Stewart Gordon
}

University of Michigan

\section{Introductory Perspective}

In the late eighteenth century in India, the forces of indigenous rulers ranged from cavalry without infantry or artillery, through cavalry supported by artillery, to mixed infantry and cavalry, to infantry with irregular cavalry. This variety continued, in spite of convincing demonstrations of the military superiority of European-style artillery and infantry forces more than 30 years earlier in campaigns involving the British and the French. The central question is, by the opening of the nineteenth century, why had so few Indian rulers adopted the European system?

The answers take us away from abstract questions of military 'efficiency' to the actual complexities of the introduction of a new technology and new military organisation. A successful military system from outside the society causes rethinking, refocusing of resources, and other sorts of stress in a society and, thus, illuminates the complex, changing and often contradictory symbolical systems which surround and embed both the existing and the challenging military systems. ${ }^{1}$ In the India of the eighteenth century, we can conceive of each court as a micro theatre in which real rulers and

Acknowledgements: I wish to acknowledge Dr Stephen Markel, Acting Curator of South Asian Art, Los Angeles County Museum, for assistance in using Mughal paintings to supplement the well-known textual sources for Mughal military history. I also wish to thank Col. David

Sa'adah (US Army, retired) for sharing his expertise on eighteenth century European warfare.

'The issue of the 'embedding' of a technology in ideas and ideology have been admirably explored in two recent books; Wiebe E. Bijker, Shaping Technology/Building Society, Cambridge, Mass., 1992, and idem, The Social Construction of Technological Systems, Cambridge, Mass., 1987.

The Indian Economic and Social History Review, 35, 3 (1998)

SAGE New Delhi/Thousand Oaks/London 
nobles weighed and contested full or partial adoption of a new military system against a variety of symbolic and structural changes and their perceived costs. ${ }^{2}$

\section{The Weaponry of Mughal India}

As a point of departure, let us consider Mughal armies, from Bahur's invading force which reached the Indian plains in the first decade of the sixteenth century through Akbar's at the end of the sixteenth century. Most obviously, this was an army of cavalry. Out of the Central Asian background, men (and women) learned to ride as early as they could walk. Most extant paintings of the Mughals at war or on the hunt show them on horseback. Babur, hearing of an opportunity for conquest more than 150 miles away, described the whirlwind activities of the next three days, as follows:

Off we hurried, that very hour-it was sunset-without reflecting, without a moment's delay ... . Through that night it was rushed without delaying anywhere, and on next day until at the Mid-day Prayer, halt was made . . . . There we cooled down our horses and gave them corn. We rode out again at beat of (twilight) drum and on through that night till shoot of dawn, and through the next day till sunset, and on through that night till, just before dawn, we were ... [at] Marghinan. ${ }^{3}$

Unlike infantry, cavalry could travel vast distances, choose where and when to fight, and disengage in an orderly, rapid, strategic retreat. Mughals were, thus, a late manifestation of an earlier and highly successful revolution in military technology, horseback warfare of the Central Asian steppe nomads. Out of these grasslands, so productive for raising horses, had come the Huns, various Turkish bands and the Mongols (under Ghenghis Khan and his successors) who invaded west into Europe, east into China, and south into the Levant.

In this tradition, the Mughals took horse grading and branding seriously. The top grade was Turki horse, followed by the Yabu, Tazi and Jangalah. The top three were larger, stronger breeds imported into India, and the lowest category was a smaller, locally-bred horse. ${ }^{4}$

\footnotetext{
2 This approach avoids consideration of overall 'superiority' or 'inferiority' of non-Western technology, a not very productive question, but one which has generated much literature, both in the West and Asia. See William McNeil, The Pursuit of Power: Technology, Armed Force and Society since A.D. 1000, Oxford, 1983. Also, A. Dharampal, Indian Science and Technology in the Eighteenth Century, Delhi, 1971; Deepak Kumar, Science and the Raj, 1857-1905, Oxford, 1995.

${ }^{3}$ Babumama, trans. A.S. Beveridge, Delhi, 1989 rpt, pp. 99-100

'Rafi A. Alavi, 'New Light on Mughal Cavalry', in Medieval India: A Miscellany, Volume 2, Aligarh, 1972, pp. 73-74; see also William Irvine, The Amy of the Indian Moghals: Its Organisation and Administration, Delhi, 1962 rpt, p. 52.
} 
Every man brings his own horse and offers himself to be inlisted [sic]. The horse; and not the man, is carefully examined; and according to the size and value of the beast, the master receives his pay. ${ }^{5}$

The downgrading of locally-bred horses was a result of how the Mughals defined warfare.

Cavalry meant heavy cavalry. A trooper normally wore linen quilting and chain mail, a helmet, plus a breastplate, back-plate, and two side plates, leg plates, arm plates, a neckpiece and gauntlets.

The principal weapon of this heavily armoured soldier on horseback was the bow, particularly the short, reverse-curve bow common to Persia and Central Asia. Recent scientific experiments have shown that this bow delivers substantially more penetrating power than any but the largest and heaviest longbows. ${ }^{6}$ Often it was made of composite materials such as wood and horn, which made it even more powerful. Unlike the longbow, it could, of course, be used from horseback. It is archery practice with the reverse-curve bow which we find both in Mughal normative texts on military practice and in actual descriptions of the daily round of Mughal armies. ${ }^{7}$

Mughal swords were curved swords, effective only for slashing from horseback. This curved sword appears in many depictions of the Mughal emperor, even when he was at leisure in his harem. ${ }^{8}$ Along with swords and daggers, ornate quivers and horse trappings were routinely given to honour meritorious actions.

And what of firearms in Mughal armies? They were not generally cintral to battle. This is corroborated in Babur's memoirs, as well as the court chronicles of his successors, Humayun and Akbar. Matchlocks had serious problems; they were heavy, inaccurate, slow to load, and could not be used from horseback. ${ }^{9}$ Even well into the seventeenth century, a cavalryman could get off six arrows in the time it took to fire a single shot from a matchlock. ${ }^{10}$ Matchlocks were basically relegated to the infantry, indigenously-recruited units held in such contempt that they were listed along with litter bearers, carpenters, wood-cutters and cotton carders in the military pay records." The only campaigns in which honourable cavalry routinely

\footnotetext{
${ }^{5}$ Robert Orme, Historical Fragments of the Mogu/ Empire, London, 1805, p. 418

${ }^{6}$ Edward McEwen, Robert L. Miller and Christopher A. Bergman, 'Early Bow Design and Construction', Scientific American, June 1991, pp. 76-82.

${ }^{7}$ For other representations of this type of army in camp and in battle, see P. Pal, Court Paintings of India, 16th-19th Centuries, New York, 1983; see also, Michael Brand and Glenn D. Lowry, Akbar's India: Art from the Mughal City of Victory, New York, 1986.

${ }^{8}$ Vishaka N. Desai, Life at Court: Art for India's Rulers, 16th-19th Centuries, Boston, 1985, Plate 71.

${ }^{9}$ Mughal paintings show these early shoulder arms in use from covered platforms mounted on the backs of elephants, but mainly in hunting.

${ }^{10}$ Francois Bernier, Travels in the Mogu/ Empire, A.D. 1656-1668, second edition (revised by Vincent A. Smith), Delhi, 1989 rpt.

"Irvine, The Army of the Indian Moghals, p. 155.
} 
used shoulder arms were in areas ol difficult terrain, such as the riverine areas of eastern Bengal and the Himalayan hills. ${ }^{12}$

Lastly, consider artillery. In virtually all paintings showing Mughal battles of the late sixteenth century, guns seem completely unintegrated into the swirl of cavalry charges. ${ }^{13}$ Documentary sources support the visual evidence that guns were slow to fire (on the order of a couple of times an hour), inaccurate, and far too heavy to move in support of cavalry movements. ${ }^{14}$ For Babur, perhaps their most important use was for holding off the initial charges of the Rajput cavalry in the battle of Khanwa (1527). Nevertheless, the battle was won by the Mughals by cavalry charge with bow and arrow and hand-to-hand combat. ${ }^{15}$ These early guns were, in fact, much more effective against forts than they were in plains battles, and this is how they are often portrayed in the paintings of the period. ${ }^{16}$ Like the infantry, the artillery branch had little prestige or chance of advancement; it was mainly staffed by 'Portuguese, English, Dutch, Germans, and French; fugitives from Goa, and from the Dutch and English companies'. ${ }^{17}$

The optimal battle situation for such an army was on the plains, where the cavalry could manoeuvre, wheel, and charge. Tactics divided the cavalry into 'wings', plus a designated vanguard and reserve. Artillery was drawn up in front and usually opened the battle, but was too heavy to move with the fighting of the remainder of the day. The main tactic was the massed charge (to the accompaniment of huge drums), using first bow and arrow, followed by hand-to-hand conibat with sword. If the line weakened, the commander (watching from his elephant) sent in reserves. The battle was decided by the death, capture or retreat of the commander, after which his army fled, leaving tents, baggage, reserve horses, the bazaar and guns as loot for the winning side.

\footnotetext{
${ }^{12}$ The use of matchlocks in river warfare in Bengal is illustrated in a dispersed page from the Beatty Collection Akbarnama now in the Cincinnati Museum. See Ellen S. Smart and Daniel S. Walker, The Pride of Princes: Indian Art of the Mughal Era in the Cincinnati Art Museum, Cincinnati, 1985. Documentary evidence corroborating this portrayal is found throughout the many battles described by Mirza Nathan, who served in Bengal for 20 years in the reign of Jahangir. See Baharistan-i-Ghaybi, trans. M.I. Borah, Assam, 1936.

13 See, for example, G.N. Pant, Mughal Weapons in the Baburnama, New Delhi, 1989, Plate 1.

14 For example, see the static arrangement of the artillery in 'A'zam Khan captures Fort Dharur' from the Royal Library, Windsor Castle, fol. 91b, published in P. Pal, Master Artists of the Imperial Mughal Court, Bombay, 1991, p. 143.

is J.N. Sarkar, Military History of India, Calcutta, 1960, p. 47.

${ }^{16} \mathrm{See}$, for example, the famous Akbamama painting by Miskina and Paras of a cannon being dragged up to the siege of Ranthambor, Victoria and Albert Museum, Acc. No. 72/117, published, among other places, in Geeti Sen, Paintings from the Akbar Nama: A Visual Chronicle of Mughal India, Calcutta, 1984.

${ }^{17}$ Bernier, Travels, p. 217
} 


\section{Paying Armies in Mughal India: Loot, Mansabdari and Watan}

For the early Mughal armies, as under Babur, loot was the most common source of pay of troopers. Loot of a nearby countryside was as common as loot following a battle. The choice of battle site was often dictated by the availability of nearby populated countryside to loot. From the nomadic background of the Mughals, we find the expected tension between the mobility and freedom of the conquering war band and the desire for stable on-going revenue. Thus, whenever Babur held a region for even one agricultural season, he promptly allotted various sections and villages to his main leaders, as their 'places' for maintenance. Babur is especially poignant on this subject. 'It passed through my mind that to wander from mountain to mountain, homeless and houseless, without country or abiding place, had nothing to recommend it.' 18

The ordinary, ongoing processes of military service in India were surprisingly similar to Babur's 'placing' of his leaders. At least as early as the fourteenth century, large groups of armed men indigenous to India sought military service, were willing to move long distances to find it and shared an ethos of service. ${ }^{19}$ Men and families sought military service for pay, booty, status and honour-but principally as entrepreneurial activity. Men joined armies for the chance to establish hereditary rights to revenue by written appointment from the ruler they served.$^{20}$ They fought to get or enhance their watan, a word used across all of India (except the extreme south) to mean core familial rights to revenue, deeply tied to sense of place. ${ }^{21}$

To get a clearer understanding of this South Asian watan process, let us look briefly at the records of the Mane family of southern Maharashtra, who served the Bijapur Sultanate in the seventeenth century, and whose watan was the area around the town of Mhasvad.

A cluster of documents from 1666-67 shows the dependence of the Adil Shah government on the Manes for local military forces and their forces in larger campaigns.

\footnotetext{
18 Baburnama, p. 153

${ }^{19}$ Dirk H.A. Kolff, Naukar, Rajput and Sepoy: The Ethnohistory of the Military Labour Market in Hindustan, 1450-1850, Cambridge, 1990.

${ }^{20}$ Ibid., pp. 63-64.

21 The first choice of term to describe the receipt of local land rights in return for military service might have been iqta. This term describes precisely the relationship between a Muslim ruler and his military followers, from the first Muslim invasions of India onwards. When the relationship moved beyond the Muslim followers to indigenous local militarised families, it was rarely termed iqta; more commmonly, these groups termed the relationship watan. I have, therefore, chosen to use the term watan. See Richard Eaton, 'Iqta tenure in the Deccan in the age of Timur', Paper Presented at the Conference on South Asia, Madison, 1996, unpublished.
} 
Sayyad Ilias Saya Khan, commander, pleased with the valour of Rataji Narsingrao Mane in repulsing the attack of Mirza Raja Jai Singh on Bijapur, recommended to Ali Adil Shah II [Sultan of Bijapur] that the deshmukhi watan of Kasbe Kaladhon be granted to Rataji Mane. So a watan sanad is issued. ${ }^{22}$

Note the term deshmukh used in this quote. Literally, it translates as 'mouth of the land'; with its use, all governments of the time recognised that these militarised local families were much more than government appointees. Their rights as deshmukh often went to a family who had either settled and developed vacant land or been instrumental in resettling land after it became vacant through war or famine. Note, also, that the location of this new grant of deshmukh in Kaladhon was in the area immediately adjacent to the core area of the Mane family holdings.

Other papers of the same months in 1766 illustrate the use of Rataji Mane's troops closer to home.

Ali Adil Shah II writes to Rataji [that] these villages are troubled by Naiji Pandre, who has claimed that he has the mokassa grant and began collecting the revenue, by force. So, proceed immediately on receipt of the firman (order), with the necessary force and give stern warning to Punjaji Jamadar, who represents said Naiji Pandre. Expel him, and warn him not to come again ... Inform us accordingly. ${ }^{23}$

Two months later, in recognition of expelling Naiji Pandre from the district, Rataji Mane was rewarded with robes of honour from the Bijapur court. 'Wear it and be honoured; you have done good service.'

In the next year, Rataji undertook two more tasks using his troops to enforce the authority of Bijapur. At the request of Ali Adil Shah II, he drove out one Kandoji from his village which had been resumed by the Adil Shahi government. A month later, Rataji was instructed by the Adil Shahi ruler to warn two Nimbalkar brothers that they should leave as they were disrupting territory belonging to Ali Adil Shah II. Presumably, Rataji completed both tasks, because he was later rewarded with robes of honour.

It hardly matters where one tracks similar family documents of men in military service in the Indian regions of Uttar Pradesh, Rajasthan, Bengal, Malwa or Maharashtra-this is the dominant pattern. These local cavalry were a ruler's most important source of troops in the countryside, probably more valuable than troops housed in the forts of the area. Muslim sultans and Hindu rajas alike used these armed local families to repel invaders, disarm rebels and join other troops as main force fighting units of the

${ }^{22}$ D.A. Pawar, ed., Tarabaikalin Kagedpatre, Kolhapur, 1969, p. 124. Translation mine, with the assistance of Dr Shiresh Chikte.

2" Ibid., p. 129. 
kingdom. Close ties between ruler and family included personal audiences frequent letters, robes of honour and, most important, written contracts to rights in their local watan area.

I want to emphasise several features of this system. First, in any region, the number of families involved in this system was large. On the central plains area of Malwa (roughly 120 miles by 150 miles), a Mughal heartland, more than 80 named, armed families possessed administrative functions similar to the Mane family of Maharashtra. All had at least mud-walled fortified houses. More than a dozen had significant stone forts. If we include the hilly areas of eastern and western Malwa, the number doubles. ${ }^{24}$

Second, this system of local troops was deeply interwined with the rhythm of the Indian agricultural year. Monsoon was the time of year for planting and harvesting; whether or not the local military family did it themselves, they had an intimate interest in the results. The end of monsoon and the Dussehra festival were the time for meeting, mustering and campaigning. Though these troops were 'available' for campaigns, they were primarily available in their local area. Kings Knew this; if one tracks the military activities of any of these armed families, once settled, they rarely travelled more than $\mathbf{5 0}$ miles from home, and not in monsoon.

Third, this whole system was defined by cavalry, men on horses. Horsemounted locally-based service was an indigenous Indian tradition. Pay at the beginning of campaign was called 'stirrup money'. We have only to look at the hero stones of the tenth to thirteenth centuries from local areas of Karnataka and Maharashtra, or tribal areas of Central India and Rajasthan, to see that the local hero and protector was mounted on horseback. ${ }^{25}$ It was horse-mounted service (and its attendant watan rewards) which differentiated the family from the surronding peasant cultivators. Virtually all the symbols of honour granted by kings to watan-holders were associated with the horse-especially khilat (robes of honour), but also horses, saddles, daggers and standards. ${ }^{26}$

Fourth, in spite of the weakening of the Mughal empire in the first half of the eighteenth century, this watan system was strengthening. Across all of northern India, Mughal officials were busily turning their regional jobs into local watans. In the riverine areas and foothills of northern India, local militarised families were strengthening their watans by eliminating detailed

\footnotetext{
${ }^{24}$ W.H. Tone, who travelled through Khandesh in the late eighteenth century, counted 20 forts in the course of a day's march. W.H. Tone, Illustrations of Some Institutions of the Maratha People, London, 1818, p. 9.

${ }^{25}$ S. Settar and Gunther D. Sontheimer, Memorial Stones: A Study of their Origin, Significance and Variety, Dharwad and Heidelberg, 1982.

${ }^{26}$ It is well known that Shivaji, founder of the Maratha polity, had infantry in nearly equivalent numbers to his cavalry and that these troops were important in battles which centred on forts in Maharashtra. Nevertheless, soon after Shivaji's death, warfare between the Mughals and the Marathas dictated rapid movement on horseback, and the infantry dwindled.
} 
revenue data which formerly flowed to the Mughal court. ${ }^{27}$ Perhaps even more interes'ing, during the seventeenth century, the whole ethos of horse service and its symbols of honour had reached people never before associated with it and was used as a means of upward social mobility. For example, in broad areas of tribal Central India, the horse-based ethos of Rajput kings displaced the indigenous tribal ethos of kingship. The process of tribals aspiring (often successfully) to become Rajputs had begun. ${ }^{28}$ In Maharashtra, horse service in the Deccan Sultanates had deeply changed the self-image of various castes into something known as 'Maratha'; it was the common traditions and symbols of cavalry service which differentiated the 'Marathas' from relatives who were cultivators, ironworkers, or shepherds. ${ }^{29}$

In summary, whereas both muskets and artillery were thoroughly embedded in an indigenous military system of symbols, practice and honour, well before the advent of the new European system in the mid-eighteenth century, cavalry was the high-prestige, high-pay branch of military service. Local militarised families pledged cavalry service against lucrative shares of local government taxation. For rulers, these forces were the principal troops in the countryside, performing police duties and joining main force armies. The symbols of honour such as robes and swords were overwhelmingly associated with horse service.

Some small evidence indicates that muskets were starting to be considered 'honourable', when carried by cavalry, who dismounted and fired.$^{30}$ Infantry, nevertheless, remained low-pay, low-prestige and rarely decisive in battle. ${ }^{31}$

The foot soldiers receive the smallest pay; and, to be sure, the musketeers cut a sorry figure at the best of times, which may be said to be when squatting on the ground, and resting their muskets on a kind of wooden fork ... . Even then, they are terribly afraid of burning their eyes or their long beards, and above all lest some Dgen, or evil spirit, should cause the bursting of their musket. ${ }^{32}$

${ }^{27}$ Muzaffar Alam, "Eastern India in the early eighteenth century "crisis"": Some evidence from Bihar', The Indian Economic and Social History Review, Vol. 28 (1), 1991, pp. 53-55.

${ }^{28}$ Surajit Sinha, 'State formation and Rajput myth in tribal central India', Man in India, Vol. 42 (1), January-March, 1962, pp. 35-75.

${ }^{29}$ See the extensive discussion of the coalescence of the Maratha caste in Stewart Gordon, Zones of military entrepreneurship in India, 1500-1700', in idem, Marathas, Marauders, and State Formation in Eighteenth-Century India, Delhi, 1994

${ }^{30}$ This appears to be the case in two mid-eighteenth century paintings, one from Central India and one from the Himalayan hills. See P. Pal, Court Paintings of India, Plate R. 33; see also, B.N. Goswamy and Eberhard Fischer, Pahari Masters: Court Painters of Northern India, Zurich, 1992, Plate 97.

${ }^{31}$ In looking at hundreds of images of Mughal and Deccan Sultanate rulers, it seems striking that I have yet to see a ruler with a firearm either in a battle or a courtly setting. The only context in which royalty regularly used firearms seems to have been hunting; rulers were, however proud of good marksmanship, and had their kills recorded in official memoirs.

32 Bernier, Travels, p. 217. 
A. 'lery remained equally low-status, if somewhat higher paid. There had, however, been solid progress in integrating the use of field guns. Mughal artillery was generally respected and feared by other Indian powers throughout the later half of the seventeenth century and into the eighteenth century. Indeed, some nobles of the seventeenth century were quite committed to the development of artillery. The best known of these was Mir Jumla, the nobleman from the Muslim state of Bijapur (in southern India) who took up Mughal service when that state was annexed. Nevertheless, guns remained heavy and slow-firing, and of limited use on the mobile battlefield dominated by cavalry. Above all, like the infantry, there was no honour or hope of gaining local tax rights for artillery service.

\section{The European Military System Reaches India}

This is the military world into which the Europeans introduced their system of warfare in the middle of the eighteenth century. Let us briefly summarise the military situation in Europe. After 1500, developments occurred in metallurgy and gun casting, the crossbow and pike and the musket, all responses to the dominance of heavy cavalry. Continual warfare spurred all manner of experiments in technology, strategy, tactics and organisation. By the opening of the sixteenth century, massed firepower of infantry could sometimes prevail against massed heavy cavalry. In the next century, muskets and pikemen still got in each other's way and were occasionally overrun by heavy cavalry. With lighter guns came the technical solution: simply attach the pike to the gun as a bayonet. Sporadic firing gave way to organised firing on command. Drill, uniforms, officer training schools and many other refinements preceded the system's introduction into India. ${ }^{33}$

By the late seventeenth century, massed infantry formed the centre of battle. This massed firepower was arranged five to six men deep, the front man firing and moving to the back to reload. Reloading was slow and cumbersome, though muskets got lighter and faster to load through the course of the eighteenth century. This massing of muskets was extremely lethal against cavalry. However, the range was short, no more than 80 yards at best. By the mid-eighteenth century, Europe's best armies could

\footnotetext{
3" For our purposes, it is enough that European armies arriving in India were quite different in organisation and focus than indigenous Indian ones. I wish to avoid the issue of whether there was a military 'revolution' in Europe in the seventeenth century. The debate goes back more than 20 years now, though Geoffery Parker's The Military Revolution: Military Innovation and the Rise of the West, Cambridge, 1998, is less than a decade old. The discussion is well summarised in C. Rogers, ed., The Military Revolution: The Debate, Boulder, 1995. Recently, some historians have moved the 'revolution' backwards and forwards from the early Middle Ages to World War I. Other historians are rethinking the whole concept. See John A. Lynn, 'The evolution of army style in the modern west, 800-2000', The International History Review, Vol. 17(3), August, 1996.
} 
sustain three rounds per minute per man. With this rate of fire, the lines thinned down to two or three men deep and stretched out.

Battlefield success, in large part, depended on rate of fire, and, therefore, training, discipline and a command structure which clearly differentiated 'officers' from 'men'. By the seventeenth century, the European knightly code of honour, with its symbols associated with individual combat and heavy cavalry had been almost entirely supplanted by a structure of honours and rewards (such as colours and insignia) for officers of infantry units.

In Europe of the late seventeenth century, artillery was still heavy and cumbersome. Over the next 50 years, however, especially in France, England and Prussia, developments in artillery were quite rapid, especially with government standardisation of bore, ball weight and firing procedure. The results were much lighter, more accurate field pieces which could keep up with marching infantry. By mid-century, these light, rapidly firing field pieces were placed at the ends of the lines of infantry to fire at an angle down the opposing lines.

What about the role of the cavalry? Commanders generally counted on the cavalry for the decisive blow to finish a battle. Recall, for example, each of Marlborough's field battles, which ended in one or several cavalry charges breaking through the opposing lines.

Cavalry was massed, in tight formation, and intended as a kind of rapidly moving, lethal battering ram aimed against the centre of opposing infantry lines. ${ }^{34}$ Cavalry used in this manner-highly disciplined, tight formations, charging the infantry lines-remained the dominant pattern throughout the eighteenth century. In part, this strategy was dictated by the men available. Recruited peasants did not have horsemanship in their backgrounds; therefore, cavalry manoeuvres were relatively simple and a matter of learned drill (much like the loading of a firearm); they were only effective with massed numbers and discipline. Most cavalry units sacrificed speed to order and only attained a gallop at the very end of a charge. ${ }^{35}$ The crucial point here is that European cavalry had a different training, structure and battlefield dynamic than cavalry warfare as practised by 'men of the horse' in India.

Let us now turn our attention to the English in India before the build up of forces caused by the worldwide campaigns between the British and the

\footnotetext{
${ }^{34}$ This argument generally follows Russell F. Weigley, The Age of Battles: The Quest for Decisive Warfare from Breitenfeld to Waterloo, Bloomington, 1991

${ }^{35}$ In the course of the eighteenth century in Europe, cavalry gradually became less central as the rate of infantry and artillery fire improved. Especially important were efforts to improve the battlefield mobility of infantry and the introduction of lighter horse-drawn artillery in the closing decades of the eighteenth century. Some infantry units of necessity were operating without cavalry, but all would have preferred having it-for skirmishing, for foraging, for frontal attacks, for flanking actions, even for filing holes in the infantry line.
} 
French in the middle decades of the eighteenth century. From small units guarding the trading factories, forces had grown to substantial size in the 1660-1680 period. For example, Bengal had a standing military of 250 infantry, supplemented by two companies of natives (a total of 135 men) and 21 pieces of cannon. Bombay had 400 Royal troops, plus two companies of Rajputs at 100 men each. ${ }^{36}$

Indigenous rules were well aware that these European traders were not like other foreign traders; they came armed and represented kings. In the late seventeenth century, a seasoned administrator of an indigenous kingdom wrote this advice to his sovereign:

Amongst the merchants, the Portuguese and the English and the Dutch and the French and the Danes and other hat-wearing merchants also do carry on trade and commerce. But they are not like other merchants. Their masters, every one of them, are ruling kings . . . . These hatwearers have full ambition to enter into these provinces to increase their territories .... They should strictly never be given places to settle .... Their strength lies in navy, guns and ammunition. ${ }^{37}$

There had been, thus, many decades of military experimentation by the English (including the recruitment of indigenous forces) by the mideighteenth century build up. During these same decades, there had been wary observation of the Europeans by indigenous rulers, but relatively few occasions to see large units in warfare.

All of this changed with the French-English warfare of the mid-eighteenth century. The French and the British brought in and raised much larger units, and put them into battle. (Clive brought 2,400 men to the Battle of Buxar in 1757. $)^{38}$ The successes of these regimental units included Bussy's campaigns in the Carnatic and Maharashtra, British victories in Bengal and Oudh, and the swift British capture of Surat. ${ }^{39}$ The European command structure allowed the unit to carry on even if the leader were injured or killed. In contrast to indigenous armies, the European units could, if necessary, retreat in order without rout.

Regiments in India operated without cavalry; it was difficult and expensive to bring horses from Europe. Experience had shown that trained

\footnotetext{
${ }^{36}$ Major Madan Paul Singh, Indian Army under the East India Company, New Delhi, 1976, p. 2.

37 'The Ajnapatra or Royal Edict', trans. S.V. Puntambekar, Journal of Indian History, Vol. 8 (2), August, 1929, pp. 212-13.

${ }^{38}$ For example, Bombay received orders to raise seven companies of 80 men each, plus an artillery company with 100 gunners. Singh, Indian Army, p. 5.

"John Lynn types the British and French armies which arrived in India in the mideighteenth century as 'state commission armies' characterised by much more sophisticated military administration, mainly paid professional troops, purchase of commissions, and lack of national or patriotic commitments. Lynn, 'Evolution', p. 537.
} 
musketeers, backed by artillery, could defeat much larger numbers of indigenous cavalry. The East India Company had experimented with indigenous cavalry, found it useful at the Battle of Buxar, but disbanded the units in 1765, genuinely afraid of what would happen if indigenous cavalry learned the techniques of massed attack which overran infantry in Europe.

The progress that the natives make in the knowledge of art of war, both in Bengal and on the coast of Coromandel is becoming a very alarming circumstance, and we are not without apprehensions the consequence of teaching them cavalry exercise..$^{40}$

In East India Company forces, there would be only a very small number of cavalry and no European units until the first decade of the nineteenth century.

The English were aware that they held a technical advantage in artillery and took vigorous steps to prevent any non-English learning their gun casting and firing techniques. The Court of Directors ordered the dismissal of all non-English foreigners and natives from artillery service and wrote, as follows:

No foreigner whether in our service or not ... nor any Indian or person of mixed breed, nor any Roman Catholic of what nation whatsoever, shall on any pretense be admitted to set foot on the laboratory or any military magazine either out of curiosity or to be employed in them, or to come near to them so as to see what is going on or contained therein. ${ }^{41}$

Indian rules quickly became aware of the convincing demonstrations of effectiveness of this new infantry/artillery system. For example, the Peshwa (the de facto ruler of one of the largest states in India), when negotiating with the British envoy from Bombay in 1756, 'expressed a definite desire to have a body of English troops and artillery in the same manner as Mohomed Ali of Arcot had been favoured by Madras'. ${ }^{42}$

Rulers were equally aware that it was not only technology they wanted; it was a whole regimental system of military organisation, including uniforms and symbols, discipline and training, command structure and battle array. They knew that this knowledge was the provenance of foreigners. If the earliest response of Indian rulers was to hire the whole system from either the English or the French, the second response was to hire Europeans who knew the system. Within a decade, some enthusiastic indigenous emulations of the regimental system emerged. Probably the best known is Mir Qasim in Bengal, who raised 25,000 infantry under Walter Reinhard

${ }^{40}$ Singh, Indian Army, p. 5.

${ }^{41}$ Quoted in Singh, Indian Army, p. 5.

${ }^{42}$ W.S. Desai, Bombay and the Marathas up to 1774, New Delhi, 1970, p. 154. 
and a regiment of gunners under Europeans. Unfortunately, much less is known about Ibrahim Gardi, who raised a similar unit at Hyderabad, based on his experience serving with Bussy in the Carnatic and Maharashtrian campaigns (this unit was destroyed at the Third Battle of Panipat, 1761).

\section{Indian Rulers and the New Military}

In the second half of the eighteenth century, however, the responses of Indian rulers to the European regimental system ranged all the way from full adoption to complete rejection. Tipu Sultan's forces, for example, had uniforms, an officer corps, insignia, training manuals and an order of battle comparable to any European army of the day..$^{43}$ No other Indian ruler of the late eighteenth century went that far. For example, Mahadji Shinde's infantry battalions (approximateiy 8,000 men under the Frenchman, De Boigne) were mixed with 20,000 cavalry raised by the older watan system. Some rulers, such as Hyderabad and Oudh, simply hired European units and kept them separate from the rest of the army. Others, such as the Peshwa, failed at hiring European units and employed Muslims trained in the new system. Still other rulers, such as Mulhar Rao Holkar in the 1760s, developed only artillery and did not hire Europeans or attempt to raise European-style infantry. Many rulers, such as the Bhonsles of Nagpur, chose completely to ignore the new system and continued to recruit cavalry on the older watan system throughout the eighteenth century.

Let me suggest that there were three reasons for this variety of response and that each individual response was in its way correct. First, along with convincing shows of strength under the best of conditions, there were equally convincing failures of the new infantry/artillery system. There were problems of scale. Small units of under 200 men (larger if unsupported by artillery) could not sustain a rate of fire necessary to stop a cavalry charge.

More serious were problems of terrain. In 1772, the British expeditionary force struggling up the Western Ghats was effectively attacked by the Peshwa's Maratha cavalry. Equally serious were problems of supply. This new army could not survive by foraging, and required a regular supply of grain and ammunition. The two major defeats of the new armies in Maharashtra. Bussy's near Aurangabad in the 1750s and the British force in the early 1770s, resulted from the cutting off of supplies (tactics which had been relatively successful against the Mughals for 100 years). Finally, as was broadly known in the eighteenth century, the new troops were cashexpensive. A campaign was as likely to stop because of lack of credit as any other reason.

\footnotetext{
${ }^{43}$ There was universal respect by Tipu's European opponents for his military organisation, training and battle tactics. He has received some recent scholarly attention. See P. Barua, 'Military developments in India, 1750-1850', Joumal of Military History, Vol. 58, November, 1994, pp. 600-604.
} 
Perhaps most serious, and completely unexamined in the scholarly literature on the Indian military in the eighteenth century was the problem of the bad fit between the infantry/artillery system and the expectations of honour and reward for a ruler's own nobles and military. Indigenous military service in India in the eighteenth century had a very specific dynamic and symbolic content. If we track, for example, the career of Malhar Rao Holkar or Mahadji Shinde (prominent Maratha generais of the mid-eighteenth century) from the 1720 s, the accoutrements and rewards of horse service are obvious. Each started as a young trooper, mustering at the end of monsoon, in a small contingent led by a relative. Through personal bravery and leadership, both received booty and the ceremonial objects conferring honour, such as ornate robes, daggers, horses and trappings. They also received the real rewards of service, rights to the government's share of revenue; in this case, both received rights in the compact region of northern Maharashtra. Advancement was very rapid, and within a decade of initial service, both men were leading large contingents of cavalry, having received the revenue grants to support them, mainly in central India. ${ }^{44}$

If we compare this cavalry-based scenario to the new infantry, such rapid advancement, such symbolic and material rewards were not possible for an ordinary infantry soldier; he was but a musket in a mass of firepower. There was no scope for individual bravery and initiative which might come to the notice of the ruler. Thus, the main effect of using these new forces was to sever the intimate relations of horse-based personal service, honour, legitimacy and reward which bound together a ruler and service military families.

In the new infantry/artillery system, only officers could claim rights to government's share of the revenue. Indeed, several Europeans, including de Boigne, Perron and Walter Reinhard, gained large estates and rights to shares of taxes. It is no surprise that these officers were treated with suspicion and hostility by Indian nobles; they were upstarts and direct rivals. $^{45}$

In states not adopting the regimental system, throughout the second half of the eighteenth century, new families continued to rise from obscurity through service and advancement in the older cavalry-based watan system. For example, we have families such as the Rastes and Patwardhans in southern Maharashtra, the Rajput states on the western rim of Malwa and the Muslim state of Bhopal in eastern Madhya Pradesh. ${ }^{46}$

4 Stewart Gordon, The Marathas, 1600-1818, Cambridge, 1993, pp. 117-18.

${ }^{45}$ C. B. Baillie Fraser, Military Memoirs of Lt. Col. Skinner, London, 1851, pp. 188-90.

${ }^{46}$ The enormous overland horse trade, which every observer noted in the seventeenth century, simply continued in the eighteenth, in the form of large annual horse fairs. See Stephen F. Dale, Indian Merchants and Eurasian Trade, 1600-1750, Cambridge, 1994, pp. 25-26. 


\section{Conclusions}

By the opening of the nineteenth century, as Barua has pointed out, there had been considerable learning by both the European colonial armies and their opposing Indian rulers. English commanders learned that the most effective way to weaken the opposition was a negotiated switch of loyalties. ${ }^{47}$ English commanders knew that because of improvements in their artillery, forts were no longer the sites of decisive battles. Calcutta, Madras and Bombay had learned that the real stakes of war were taxation rights, not trading rights. They further learned that the indigenous banking system was capable of providing enough credit, pledged against future tax revenues, for a large campaign, and was capable of delivering cash to the field. Commanders well understood the rhythm of the campaigning season and the necessity of monsoon shelter.

On the Indian side, there had also been considerable learning. Like European kings, Indian rulers knew only too well the vagaries of armies loyal to kinsmen or based on 'feudal' levies. In the late eighteenth century, Indian rulers learned that loyalty could be bought with regular cash salaries, training, and uniforms. They understood the value of a unit which could retreat without rout. Many built armouries and regular garrisons for the troops during monsoon. Like their European opponents. Indian rulers developed relations with indigenous bankers capable of advancing the cash necessary to pay the troops.

Nevertheless, the unsolvable problem for Indian rulers went beyond strategy or military organisation. Real commitment to the new system (Shinde, Tipu, Ranjit Singh) meant jettisoning the older nobility and the watan structure on which it was based. This was true for two reasons. To pay the new European-style forces, the ruler needed the revenue alienated to nobles in watan. Also, the new battles gave no scope for the older nobility to prove their prowess and enhance their watans. The Peshwa's newswriter at Shinde's court (in the early 1780s) recognised the problem when he wrote, as follows:

As for his army expenditure, the Maratha forces from the Deccan have been suffering appalling miseries which $\mathrm{I}$ am unable to describe in words. They are not able to pay off their debts even by selling their horses. A trooper hardly gets Rs 10 a month; how can he live on this? Mahadji [Shinde] has spent tremendously on his new regiments of infantry, but his eminent Maratha assistants, who laid down their lives capturing Gohad and Gwalior, have suffered terrible destitution. ${ }^{48}$

\footnotetext{
${ }^{47}$ Barua, 'Developments', pp. 613-14.

${ }^{48}$ Quoted in G.S. Sardesai, Main Currents of Maratha History, Bombay, revised edition, 1949, p. 148.
} 
Throughout the 1780 s, Shinde dropped Maratha cavalry which had been recruited by the old watan system and hired Muslims, Rajputs and Gosains on cash salaries. ${ }^{49}$

The strongest commitment to the new style of army appears to have come from rulers with the least overall commitment to an older watanbased nobility. Illegitimate heirs such as Shinde, usurpers such as Tipu, Ranjit Singh as the leader of a 'peasant' based movement, pretenders such as Ragnath Rao, and women rulers such as Begam Samru readily adopted the new forces, sometimes initially against their own hostile nobility and local militarised groups.

It is also noteworthy that the new forces were adopted only by larger territorial rulers. Rulers throughout India seemed well aware that only large states, with prospects of regular income, could afford to pay European officers and the infantry. Perhaps smaller states were also aware that the new system was only effective in large scale, and that a long-term commitment to a substantial regular flow of cash required a tax-collecting and credit structure beyond their means.

Throughout the eighteenth century, there is little evidence that rulers developed new symbolic structures to tie infantry in bonds of legitimacy and loyalty, as the older horse-based honours of robes, daggers, trappings and jewels had tied the cavalry to the king. The important exception was Tipu Sultan, who developed regimental colours, medals and a whole range of honours associated with European armies of the time. ${ }^{50}$ Crucially, no Indian ruler was able to convert his watan-based cavalry leaders into efficient, trained, well rewarded leaders of infantry units. All Indian rulers were forced to rely on Europeans, whose loyalty was never tied to the ruler with the complex of symbols, landholding, and often kinship which tied the king to the older nobility.

In the eighteenth century, a king experienced problems whichever military system he chose. He either cobbled nobles and local military families into an effective cavalry force by the watan system or tried to find enough taxes and creditors to pay the wages of the new artillery/infantry units. Neither path was 'right' or 'wrong'. Each king, pretender, or usurper made his best judgement about his situation.

Finally, I wish to emphasise that adoption of the European regimental system was not the deciding factor in a state's survival. Eighteenth and early nineteenth century India was not some sort of Darwinian situation,

\footnotetext{
${ }^{49}$ The British Resident thought that Shinde was but little inconvenienced by the desertion of the unpaid Maratha troops and their leaders, as others were readily available. See India Office Library, Bengal Political and Secret Proceedings, June-September 1786, pp. 476-80.

${ }^{50}$ Indian rulers, by and large, retained the same horse-based honours right through the British conquest of India. See Kate Brittlebank, 'Curiosities, conspicuous piety and the maker of time: Some aspects of kingship in eighteenth-century South India', South Asia, Vol. 16 (2), 1993, pp. $45-46$
} 
with those states adopting the new system somehow forcing out 'conservatives' who retained the older cavalry system. If we track the survival of states as princely states into the nineteenth century, some of the militarily adaptive states like Shinde survived, some like Tipu did not. Likewise, hundreds of the smaller states based on cavalry and familial entrepreneurship survived as princely states in the nineteenth century. If anything, many more of the states based on watan and cavalry survived because they threatened British colonial power far less than larger states with infantry forces, such as Ranjit Singh's Punjab or Tipu's Mysore. 